\title{
Pengaruh Substitusi Ransum Komersil dengan Tepung Kulit Pisang Fermentasi + Feed Supplement terhadap Berat dan Persentase Organ Dalam Ayam Broiler
}

\author{
(Effect Utilization of Fermented Banana Peel + Coconut Meal + Feed Suplement to \\ the Weight and Percentage of Several Broiler Internal Organs)
}

\author{
Muhammad Daud, Zulfan, Syafriadi \\ Program Studi Peternakan, Fakultas Pertanian, Universitas Syiah Kuala
}

\begin{abstract}
Abstrak: Tujuan penelitian ini adalah untuk mengetahui pengaruh substitusi sebagian ransum komersil periode finisher dengan tepung kulit pisang kepok fermentasi+bungkil kelapa+feed supplement terhadap berat dan persentase organ dalam ayam broiler. Penelitian dilakukan di Laboratorium Lapangan Peternakan (LLP), Fakultas Pertanian, Universitas Syiah Kuala, tanggal 1 April-5 Mei 2016. Penelitian ini menggunakan 100 ekor anak ayam broiler (DOC) strain lohman. Perlakuan yang dicobakan adalah pemberian tepung kulit pisang kepok fermentasi+bungkil kelapa+feed supplement sebanyak 0\% $\left(\mathrm{P}_{1}\right), 2,5 \%+1,5 \%+1 \%\left(\mathrm{P}_{2}\right), 5 \%+3 \%+1 \%\left(\mathrm{P}_{3}\right)$. $7,5 \%+4,5 \%+1 \%\left(\mathrm{P}_{4}\right)$, dan $10 \%+6 \%+1 \%\left(\mathrm{P}_{5}\right)$. Parameter yang diamati meliputi berat dan persentase organ saluran pencernaan (crop, gizzard, dan usus), organ pembantu pencernaan (hati dan pankreas), organ sirkulasi (jantung, darah, dan limpa), lemak abdomen, dan organ nonkarkas bagian luar (bulu, kepala+leher, dan shank). Hasil penelitian memperlihatkan bahwa substitusi ransum komersil dengan tepung kulit pisang fermentasi sebanyak 10\%+bungkil kelapa 6\%+feed supplement $1 \%$ tidak berpengaruh nyata $(\mathrm{P}>0.05)$ terhadap berat dan persentase semua organ dalam ayam broiler ayam broiler. Meskipun secara statistik tidak berbeda nyata, Penggunaan tepung kulit pisang fermentasi kepok fermentasi cenderung menurunkan persentase organ-organ nonkarkas bagian luar (bulu, kepala+leher, dan shank) ayam broiler.
\end{abstract}

Kata Kunci: broiler, organ dalam, kulit pisang, fermentasi

\begin{abstract}
Abstrak: The aim of present study was to determine effect of partial substitution of commercial broiler finisher ration with a fermented banana peel+coconut meal+feed supplement to the weight and the percentage of several broiler internal organs. The study was conducted in Field Laboratory, Livestock Department, Faculty of Agriculture, Syiah Kuala University, April 1 until Mei5, 2016. As many as 100 chicks, strain lohmann, produced by PT. Japfa, Medan were used in this study. The treatment was the provision of fermented banana peel + coconut meal + feed supplement with the level of $0 \%\left(\mathrm{P}_{1}\right), 2,5 \%+1,5 \%+1 \%\left(\mathrm{P}_{2}\right), 5 \%+3 \%+1 \%\left(\mathrm{P}_{3}\right) .7,5 \%+4,5 \%+1 \%\left(\mathrm{P}_{4}\right)$, and $10 \%+6 \%+1 \%\left(\mathrm{P}_{5}\right)$, respectively. The parameters observed were the weight and percentage of internal broiler organs (crop, gizzard, small intestine, liver, pancreas, hearth, blood, spleen, and abdominal fat) as well as external noncarcass organs (feather, head+neck, and shank). The results of study showed that administration of up to $10 \%$ fermentedbanana peel $+6 \%$ coconut meal $+1 \%$ feed supplement as partial substitution of commercial finisher broiler ration was not significant effect $(\mathrm{P}>0.05)$ on the weight and percentage of internal broiler organs. Despite, statistically no significant differences were detected, the percentage of non carcass organs tend to decline as broilers fed the commercial rations partially substituted by a fermented banana peel+coconut meal+feed supplement.
\end{abstract}

Key words: broiler, internal organ, fermentation, banana peel

\section{PENDAHULUAN}

Ayam broiler atau dikenal juga dengan ayam pedaging merupakan jenis ayam ras unggulan hasil persilangan dari bangsa-bangsa ayam yang memiliki daya produktivitas tinggi, terutama dalam memproduksi daging.Pemeliharaan ayam broiler membutuhkan waktu yang relatif singkat. Dikarenakan kemampuan produksi dagingnya yang tinggi, peternakan ayam broiler di Indonesia semakin berkembang. Namun demikian, banyak kendala ditemui dalam pemeliharaan ayam broiler, antara lain adalah tingginya harga pakan.

Pakan merupakan salah satu faktor yang memegang peranan penting dalam proses produksi dengan biaya yang mencapai $70-80 \%$ dari total biaya produksi. Besarnya biaya pakan menuntut upaya untuk bisa memperoleh bahan pakan alternatif, murah, mudah didapat, dan kandungan nutrisi yang baik. Bahan-bahan pakan dimaksud umumnya berasal dari limbah-limbah pertanian, antara lain adalah kulit pisang kepok. 
Kulit pisang merupakan bahan pakan hasil limbah pertanian yang memiliki nutrisi yang baik. Menurut Hernawati dan Ariyani (2007) dan Koni (2009), kulit pisang kepok (Musa paradisiaca normalis) mengandung protein kasar sebesar 3,63\%, sedangkan lemak kasar $2,52 \%$, serat kasar 18,71\%, kalsium 7,18\%, fosfor 2,06\%, dan gross energy $3.680 \mathrm{kkal}$. Kendala bahan pakan limbah pertanian selain memiliki kandungan antinutrisi, kandungan proteinnya rendah sebaliknya serat kasar tinggi. Oleh karena itu, kulit pisang kepok perlu diolah terlebih dahulu agar dapat dimanfaatkan secara optimal, misalnya difermentasi. Menurut Udjianto et al. (2005), kulit pisang yang difermentasi dengan probiotik meningkat kandungan protein kasar menjadi 14,88\% dan serat kasar menurun menjadi 11,43\%. Limbah kulit pisang dapat dimanfaatkan untuk pakan ternak (Koni et al., 2006).

Untuk menyeimbangkan kembali kandungan protein di dalam ransum maka dapat ditambahkan bahan pakan sumber protein lainnya yang harganya relatif murah dan mudah diperoleh, antara lain adalah bungkil kelapa. Bungkil kelapa merupakan limbah dari pabrik minyak kelapa. Menurut Hartadi et al. (1980), bungkil kelapa mengandung protein sebesar 24,4\%. Zat-zat gizi lainnya dapat dilengkapi dengan penggunaan feed supplement. Feed supplement merupakan bahan makanan berupa campuran preparat vitamin, mineral, dan antibiotika guna melengkapi ransum (Sudaryani dan Santoso, 2003).

Penggunaan bahan-bahan pakan alternatif dari limbah mungkin saja tidak selamanya dapat diterima oleh ayam. Ukuran organ dalam dapat menjadi salah satu petunjuk normal atau tidaknya kesehatan ayam. Ukuran organ dalam yang membesar ataupun mengecil dapat dijadikan petunjuk adanya zat-zat berbahaya di dalam ransum ataupun air minumnya. Berdasarkan hal tersebut, penelitian penggunaan tepung kulit pisang kepok fermentasi dan bungkil kelapa sebagai substitusi sebagian ransum komersil perlu diamati pengaruhnya terhadap organ-organ dalam ayam broiler. Tujuan penelitian adalah untuk melihat pengaruh pemberian ransum komersil yang sebagian disubstitusi dengan tepung kulit pisang kepok fermentasi+bungkil kelapa+feed supplement terhadap berat dan persentase beberapa organ dalam ayam broiler.

\section{MATERI DAN METODE}

\section{Tempat dan Waktu Penelitian}

Penelitian ini dilakukan diLaboratorium Lapangan Peternakan (LLP), Jurusan Perternakan, Fakultas Pertanian, Universitas Syiah Kuala, Banda Aceh tanggal 1 April sampai dengan 5 Mei 2016.

\section{Materi, Bahan, dan Alat Penelitian}

Materi yang digunakan dalam penelitian ini adalah anak ayam broiler strain loghmann. Bahan yang digunakan terdiri dari ransum komersil broiler R511 dan R512 Bravo, kulit pisang kepok, bungkil kelapa, ragi tape, feed supplement, vaksin ND dan gumboro, desinfektan, kapur, litter, vitachick, vitastress, dan kantung plastik. Peralatan yang digunakan terdiri dari tempat pakan, tempat minum, bola lampu pijar, nampan, dandang, kukusan, disc mill, alat peniris, dantimbangan digital.

\section{Ransum Perlakuan}

Penelitian ini menggunakan ransum dasar berupa ransum komersil broiler 511 dan 512 Bravo. Ransum 511 Bravo digunakan selama periode starter (0-3 minggu), sedangkan ransum 512 Bravo digunakan selama periode finisher (4-5 minggu). Ransum komersil 512 Bravo sebagian disubstitusi dengan 2,5-10\% tepung kulit pisang kepok fermentasi + 1,5-6,0\% bungkil kelapa $+1,0 \%$ feed supplement. Ransum perlakuan adalah sebagai berikut: 
$\mathrm{P}_{1}$ : Ransum komersil broiler 512 Bravo $100 \%+$ tepung kulit pisang fermentasi $0 \%+$ bungkil kelapa $0 \%$ (kontrol) + feed supplement $0 \%$.

$\mathrm{P}_{2}$ : Ransum komersil broiler 512 Bravo 95,0\% + tepung kulit pisang fermentasi 2,5\% + bungkil kelapa $1,5 \%$ + feed supplement $1,0 \%$.

$\mathrm{P}_{3}$ : Ransum komersil broiler 512 Bravo $91.0 \%+$ tepung kulit pisang fermentasi $5.0 \%+$ bungkil kelapa 3,0\% + feed supplement $1,0 \%$.

$\mathrm{P}_{4}$ : Ransum komersil broiler 512 Bravo 87.0\% + tepung kulit pisang fermentasi $7,5 \%$ + bungkil kelapa $4,5 \%+$ feed supplement $1,0 \%$

$\mathrm{P}_{5}$ : Ransum komersil broiler 512 Bravo 83\% + tepung kulit pisang fermentasi 10,0\%+bungkil kelapa 6,0\%+feed supplement $1,0 \%$.

Tabel 1. Susunan dan Kandungan Zat Gizi Ransum Penelitian

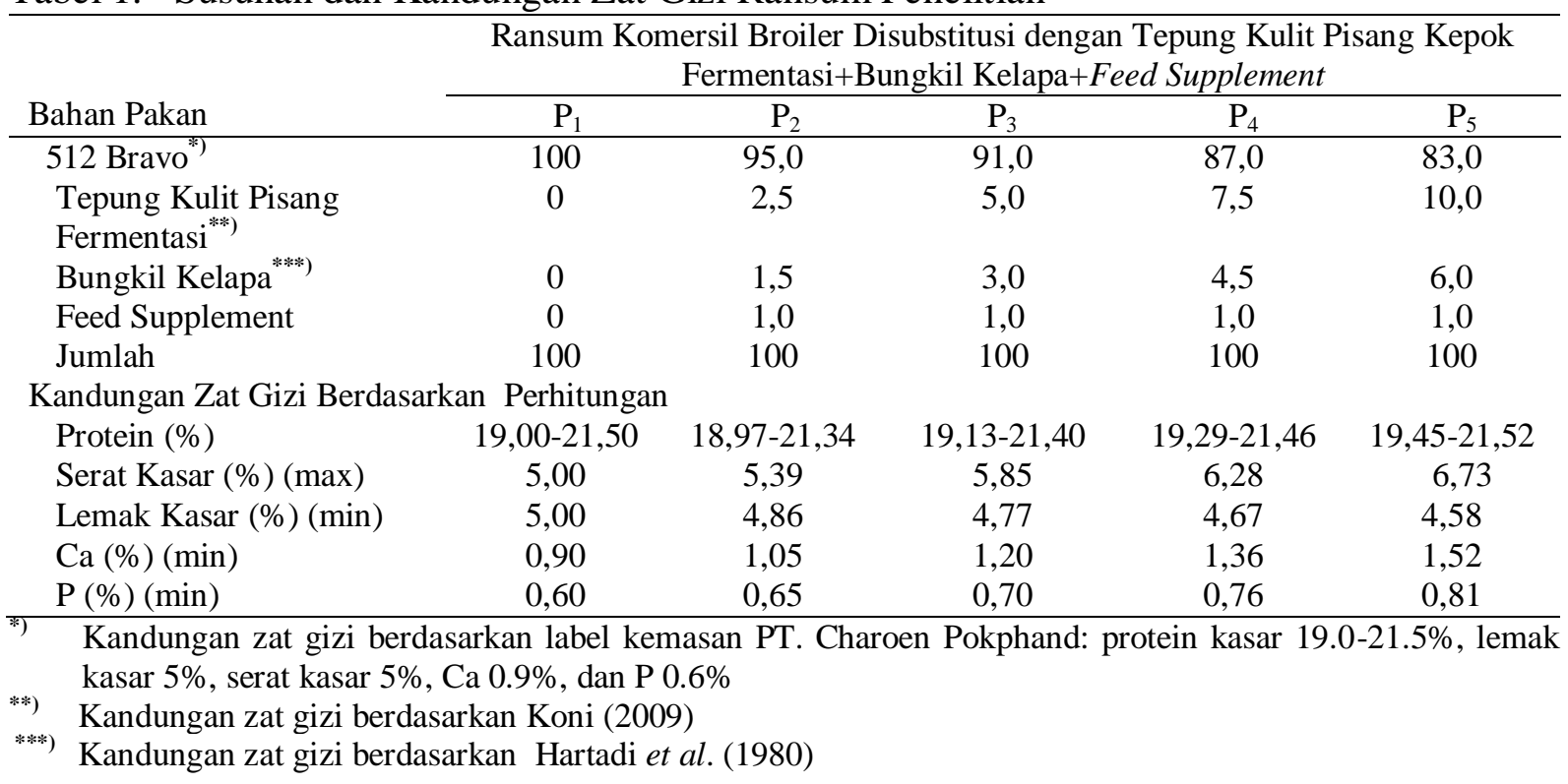

\section{Rancangan Penelitian}

Rancangan penelitian yang digunakan adalah Rancangan Acak Kelompok dengan subsampel (block randomized design with subsamples) terdiri dari 5 perlakuan, 5 kelompok, dan 2 subsampel. Setiap kelompok merupakan unit percobaan yang masing-masing terdiri dari 5 ekor ayam. Perlakuan yang diberikan adalah penggunaan ransum komersil broiler 512 Bravo yang sebagian disubstitusi dengan tepung kulit pisang fermentasi+bungkil kelapa+feed supplementdengan level berbeda.

Model matematis penelitian yang digunakan menurut Steel dan Torrie (1993) adalah:

$Y_{i j k}=\mu+\tau_{i}+\varepsilon_{i j}+d_{i j k}$

Keterangan:

$Y_{i j k} \quad$ : Nilai pengamatan

$\mu \quad$ : Nilai tengah umum

$\tau_{i} \quad$ : Pengaruh percobaan ke- $i$

$\varepsilon_{i j} \quad:$ Pengaruh galat percobaan ke- $i$ ulangan ke- $j$

$d_{i j k} \quad$ : Pengaruh galat percobaan ke- $i$ ulangan ke-j sub sampel ke- $k$ 


\section{Pembuatan Tepung Kulit Pisang Fermentasi}

Proses pembuatan tepung kulit pisang fermentasi dilakukan dengan tahapan sebagai berikut: (1) kulit pisang kepok dikumpulkan dari pedagang pisang goreng, kemudian kulit pisang dicuci, (2) kulit pisang yang sudah bersih dipotong kecil-kecil dengan ukuran $\pm 5 \mathrm{~cm}$, lalu dikukus selama \pm 25 menit untuk mematikan kuman pathogen, (3) kulit pisang dianginanginkan, (4) setelah dingin, kulit pisang dicampur ragi sebanyak $3 \mathrm{~g} / \mathrm{kg}$, (5) kulit pisang yang bercampur ragi dibungkus di dalam kantung plastik tidak padat agar jamur dapat tumbuh optimum selama empat hari, dan disimpan pada suhu kamar selama 48 jam, (6) kulit pisang fermentasi dikeringkan, lalu digiling hingga menjadi tepung.

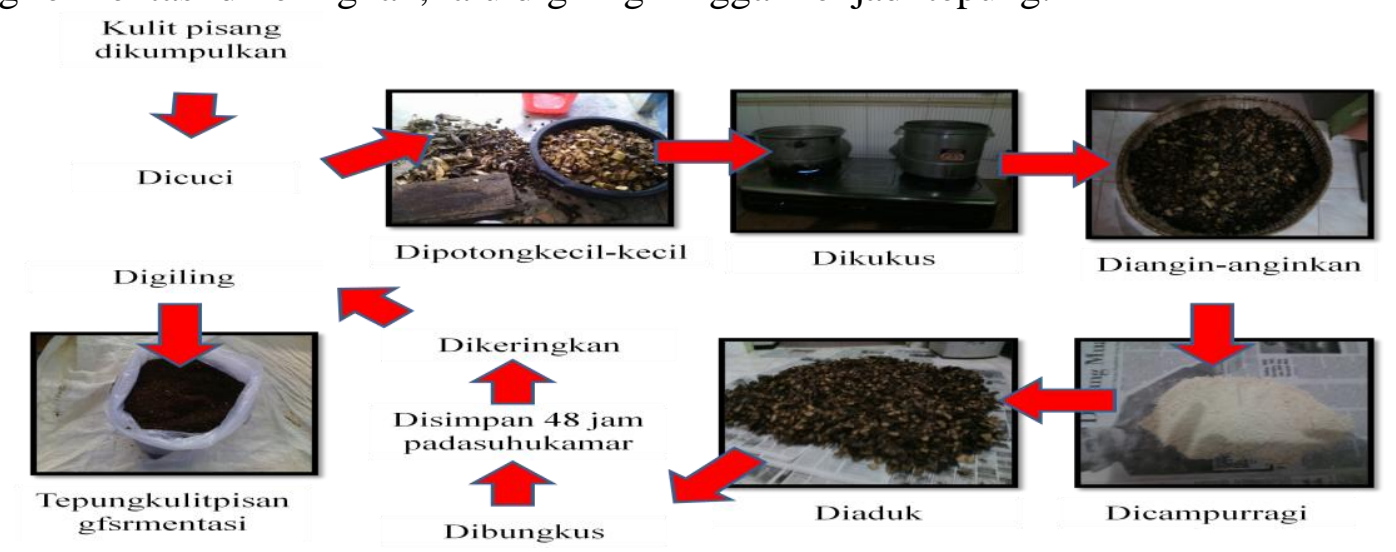

Gambar 1. Skema Proses Pembuatan Tepung Kulit Pisang Fermentasi

\section{Parameter Penelitian}

Parameter yang diamati dalam penelitian ini meliputi bobot dan persentase organ saluran pencernaan (crop, gizzard, usus), bobot dan persentase organ pembantu pencernaan (hati, pancreas), bobot dan persentase organ sirkulasi (darah, jantung, limpa), bobot dan persentase organ luar (bulu, kepala+leher, shank), bobot dan persentase lemak abdomen, dan mortalitas.

\section{Pelaksaan Penelitian}

Penelitian ini dilakukan dalam tiga tahap, yaitu:

1. Tahap Persiapan

Tahap persiapan terdiri dari persiapan kandang dan ransum. Persiapan kandang meliputi pembersihan kandang, sanitasi kandang (dalam dan sekitar kandang), pencucian, penyemprotan desinfektan, pengapuran, persiapan tempat pakan dan tempat minum, dan pembuatan unit-unit percobaan. Unit percobaan dibuat sebanyak 20 buah, masing-masing berukuran $70 \times 70 \mathrm{~cm}$. Tiap unit percobaan dilengkapi dengan pemanas berupa bola lampu pijar dengan daya 40 watt. Masing-masing unit percobaan diberi kode perlakuan secara acak.

Persiapan ransum meliputi formulasi ransum, pembuatan tepung kulit pisang fermentasi dan pencampuran ransum. Formulasi ransum dilakukan berdasarkan perlakuan yang diberikan. Bahan-bahan penyusun, berupa ransum komersil, tepung kulit pisang fermentasi, bungkil kelapa, dan feed supplement. Pencampuran ransum dilakukan berdasarkan komposisi ransum yang dibuat, dilakukan pada awal minggu keempat dan kelima.

2. Tahap Pemeliharaan

Pemeliharaan dibagi ke dalam periode starter (0-3 minggu) dan finisher (4-5 minggu). Selama periode starter, ayam dari semua perlakuan diberikan $100 \%$ ransum 
komersil $\mathrm{R}_{511}$. Selama periode finisher, ayam dari perlakuan kontrol $\left(\mathrm{P}_{1}\right)$ diberikan $100 \%$ ransum komersil $\mathrm{R}_{512}$, sedangkan perlakuan $\mathrm{P}_{2}-\mathrm{P}_{5}$, diberikan ransum komersil $\mathrm{R}_{512}$ yang disubstitusi dengan tepung kulit pisang fermentasi+bungkil kelapa sebanyak 4-16\%+1\%. Ransum diberikan ad libitum dengan pemberian dua kali sehari, yaitu pukul 08.00 dan 17.00 WIB.

Vaksinasi yang dilakukan adalah ND dan gumboro (Infectious Bursal Disease). Vaksinasi ND dilakukan pada umur 3 hari via tetes mata dan diulangi pada umur 21 hari melalui suntikan intramuskuler. Vaksinasi gumboro dilakukan pada umur 12 hari melalui tetes mulut.

c. Tahap Pengambilan Data

Tahap pengambilan data dilakukan pada akhir penelitian (hari ke-35).Semua ayam ditimbang untuk mengetahui rata-rata berat badan akhirnya. Sebanyak dua ekor ayam diambil dari masing-masing unit percobaan dengan kriteria rata-rata berat badannya mendekati rata-rata berat badan unit percobaannya. Ayam selanjutnya dipotong, dikeluarkan darah, lalu ayam tanpa darah ditimbang. Ayam dicabut bulu, kemudian ayam tanpa bulu ditimbang. Kepala dan leher serta shank dipisahkan, kemudian masingmasing ditimbang. Organ-organ tubuh bagian dalam dikeluarkan, lalu dipisahkan bagianbagiannya dan ditimbang. Lemak abdomen dipisahkan dari rongga perut, kemudian ditimbang.

\section{Analisis Data}

Data yang diperoleh akan diolah secara statistik dengan menggunakan analysis of variance (ANOVA). Jika diantara perlakuan terdapat perbedaan yang nyata $\left(\mathrm{F}_{\text {hit. }}>\mathrm{F}_{\text {tabel }}\right.$ $\alpha=0.05$ ) maka dilakukan uji lanjut dengan menggunakan Uji Jarak Berganda Duncan (Duncan Multiple Range Test) (Steel dan Torrie, 1993).

\section{HASIL DAN PEMBAHASAN}

\section{Berat dan Persentase Organ Saluran Pencernaan}

Rataan berat dan persentase beberapa organ saluran pencernaan ayam broiler yang diberi ransum komersil yang disubstitusi dengan tepung kulit pisang kepok fermentasi+bungkil kelapa+feed supplement selama periode finisher (4-5 minggu) diperlihatkan pada Tabel 2. Hasil sidik ragam menunjukkan bahwa substitusi sebagian ransum komersil dengan tepung kulit pisang kepok fermentasi sampai 10\%+bungkil kelapa $6 \%+$ feed supplement $1 \%$ selama periode finisher tidak berpengaruh nyata $(\mathrm{P}>0.05)$ terhadap berat dan persentase beberapa organ saluran pencernaan, seperti tembolok, rempela, dan usus ayam broiler. Rataan persentase bobot organ saluran percernaan ayam broiler dalam penelitian ini termasuk dalam batas normal. Hal ini menunjukkan bahwa tepung kulit pisang kepok fermentasitidak memberikan pengaruh negatif terhadap organ-organ pencernaan ayam broiler.

Rataan persentase crop ayam broiler dari semua perlakuan dalam penelitian ini berkisar $0,14-0,25 \%$. Meskipun terlihat ada sedikit peningkatan persentase crop pada ayam-ayam yang diberikan $10 \%$ tepung kulit pisang kepok fermentasi $+6 \%$ bungkil kelapa $+1 \%$ feed supplement selama periode finisher $\left(\mathrm{P}_{5}\right)$, perbedaan secara statistik tidak nyata. Hal ini dikarenakan tembolok hanyaberfungsi menyimpan makanan sementara untuk dilumatkan (Anggorodi, 1985). Tidak ada enzim yang disekresikan di dalam tembolok, namun terdapat enzim yang berasal dari saliva yang terbawa dengan makanan ke dalam tembolok. 
Tabel 2. Berat dan Persentase Beberapa Organ Saluran Pencernaan Ayam Broiler yang Diberi Ransum Komersil yang Disubstitusi Tepung Kulit Pisang Fermentasi+Bungkil Kelapa+Feed Supplement selama Periode Finisher

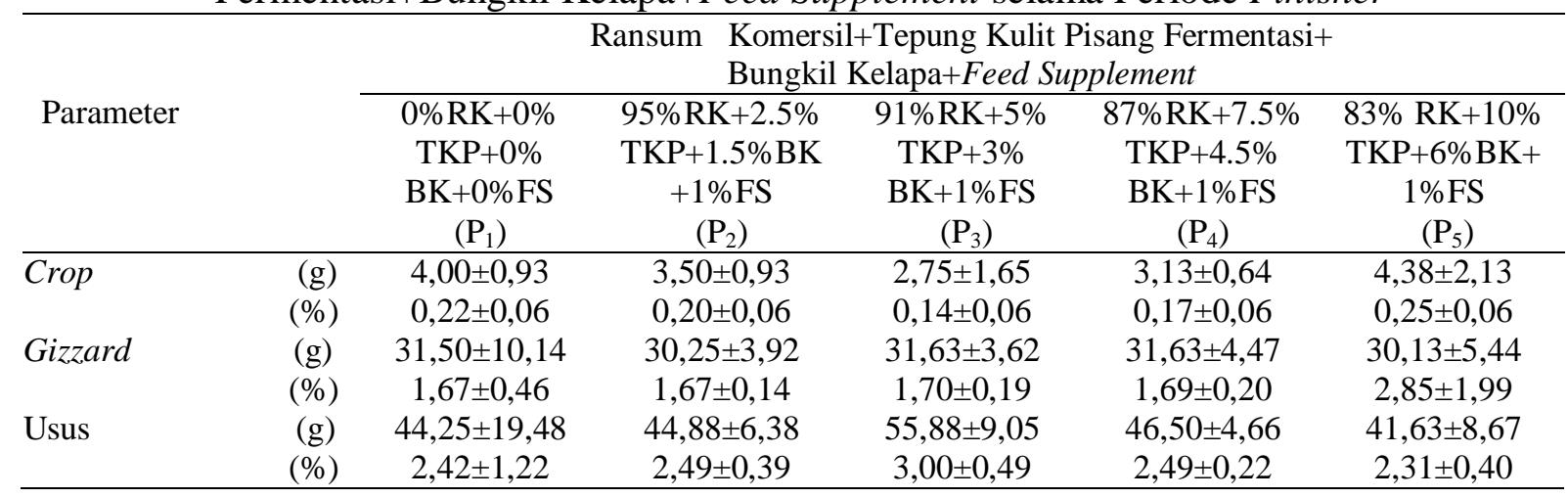

Hasil penelitian ini memperlihatkan ayam-ayam yang diberi ransum yang mengandung tepung kulit pisang kepok fermentasi+bungkil kelapa cenderung memiliki rataan persentase gizzard sedikit lebih tinggi, terutama pada penggunaan $10 \%$ tepung kulit pisang fermentasi+6\% bungkil kelapa. Hal ini dikarenakan tepung tepung kulit pisang fermentasimasih mengandung serat kasar yang tinggi (Koni et al., 2006), demikian pula halnya dengan bungkil kelapa (Zamora et al., 1989). Rempela (gizzard) sangat berperan dalam proses pencernaan unggas untuk memperkecil ukuran partikel makanan dengan cara menggiling dan memecahnya menjadi lebih kecil (Pond et al., 1995). Gizzard akan meningkatkan aktivitasnya dengan semakin sulit makanan dicerna, mengakibatkanukurannya bertambah (Kismono, 1986). Namun demikian, rataan persentase gizzard ayam broiler dari semua perlakuan dalam penelitian ini termasuk normal dengan kisaran 1,67-2,85\%, sesuai dengan yang dilaporkan Ramli et al. (2008), persentase rempela ayam broiler penelitiannya berkisar $1,88-2,23 \%$ dan termasuk normal.
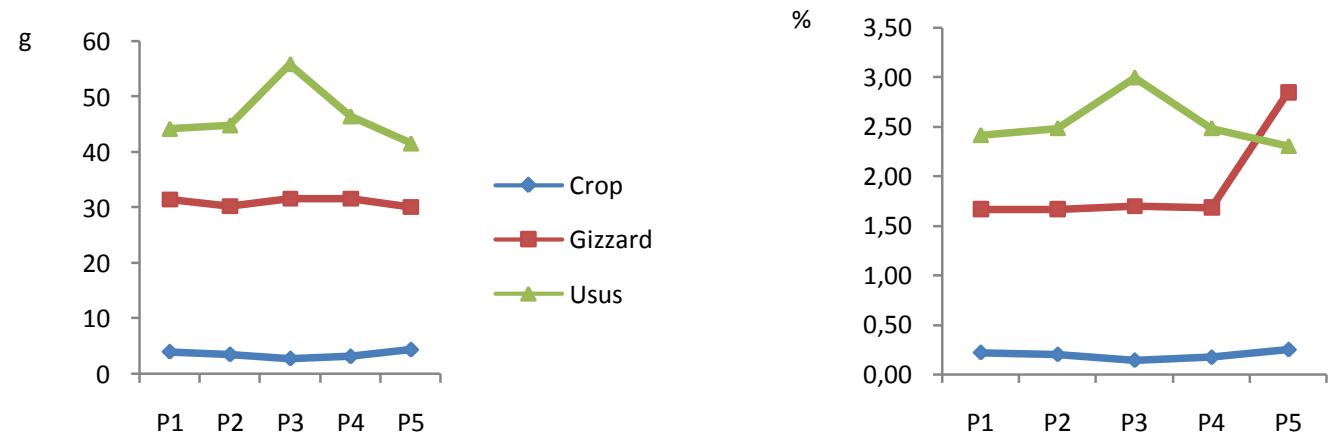

Gambar 2. Berat dan Persentase Crop, Gizzard, dan Usus Ayam Broiler Penelitian dari Semua Perlakuan

Usus halus berfungsi sebagai organ pencernaan makanan dan mengabsorbsi nutrisi bahan pakan. Kandungan serat kasar yang tinggi di dalam ransum dapat menyebabkan ukuran usus lebih besar (Sturkie, 1976). Namun demikian, ayam-ayam yang diberi ransum yang mengandung tepung kulit pisang kepok fermentasi+bungkil kelapa+feed supplement selama periode finisher tidak memperlihatkan adanya peningkatan persentase usus. Ini berarti bahwa tepung kulit pisang kepok fermentasi dapat dicerna dengan baik di dalam usus ayam broiler selama periode finisher. Rataan persentase usus halus ayam broiler dari semua perlakuan dalam penelitian ini termasuk normal, dengan kisaran 2,31-3,0\%, namun lebih rendah dari yang dilaporkan oleh Ramli et al. (2008), yaitu 4,44-5,35\%. Perbedaan ini 
dikarenakan bagian usus yang ditimbang dalam penelitian ini hanya usus halus, sedangkan penelitian Ramli et al. (2008) termasuk ceca dan rectum.

\section{Berat dan Persentase Organ Pembantu Pencernaan}

Rataan berat dan persentaseorgan-organ pembantu pencernaan ayam broiler yang diberi ransum komersil yang disubstitusi dengan tepung kulit pisang kepok fermentasi+bungkil kelapa+feed supplement selama periode finisher (4-5 minggu) diperlihatkan pada Tabel 3. Hasil sidik ragam menunjukkan bahwa pemberian tepung kulit pisang kepok fermentasi+bungkil kelapa+feed supplementselama periode finisher tidak berpengaruh nyata $(\mathrm{P}>0.05)$ terhadap berat dan persentase beberapa organ pembantu pencernaan ayam broiler, seperti hati dan pankreas. Rataan persentase organ saluran pembantu percernaan ayam broiler dalam penelitian ini termasuk dalam batas normal. Hal ini menunjukkan bahwa tepung kulit pisang kepok fermentasitidak memberikan pengaruh negatif terhadap organ-organ pembantu pencernaan ayam broiler.

Tabel 3. Berat dan Persentase Beberapa Organ Pembantu Pencernaan Ayam Broiler yang Diberi Ransum Komersil yang Disubstitusi Tepung Kulit Pisang Fermentasi+Bungkil Kelapa+Feed Supplement selama Periode Finisher

\begin{tabular}{lcccccc}
\hline & \multicolumn{5}{c}{ Ransum } & \multicolumn{5}{c}{ Komersil+Tepung Kulit Pisang Fermentasi+ } \\
& & \multicolumn{5}{c}{ Bungkil Kelapa+Feed Supplement } \\
\cline { 2 - 7 } Parameter & $0 \% \mathrm{RK}+0 \%$ & $95 \% \mathrm{RK}+2.5 \%$ & $91 \% \mathrm{RK}+5 \%$ & $87 \% \mathrm{RK}+7.5 \%$ & $83 \% \mathrm{RK}+10 \%$ \\
& & $\mathrm{TKP}+0 \%$ & $\mathrm{TKP}+1.5 \% \mathrm{BK}+$ & $\mathrm{TKP}+3 \%$ & $\mathrm{TKP}+4.5 \%$ & $\mathrm{TKP}+6 \% \mathrm{BK}+$ \\
& & $\mathrm{BK}+0 \% \mathrm{FS}$ & $1 \% \mathrm{FS}$ & $\mathrm{BK}+1 \% \mathrm{FS}$ & $\mathrm{BK}+1 \% \mathrm{FS}$ & $1 \% \mathrm{FS}$ \\
& & $\left(\mathrm{P}_{1}\right)$ & $\left(\mathrm{P}_{2}\right)$ & $\left(\mathrm{P}_{3}\right)$ & $\left(\mathrm{P}_{4}\right)$ & $\left(\mathrm{P}_{5}\right)$ \\
\hline \multirow{2}{*}{ Hati } & $(\mathrm{g})$ & $44,50 \pm 8,70$ & $46,88 \pm 9,34$ & $37,00 \pm 5,53$ & $38,63 \pm 7,17$ & $43,00 \pm 6,55$ \\
& $(\%)$ & $2,44 \pm 0,76$ & $2,59 \pm 0,46$ & $1,99 \pm 0,31$ & $2,06 \pm 0,30$ & $2,40 \pm 0,39$ \\
Pankreas & $(\mathrm{g})$ & $3,75 \pm 1,16$ & $3,31 \pm 0,59$ & $3,75 \pm 0,46$ & $3,00 \pm 1,07$ & $3,50 \pm 0,76$ \\
& $(\%)$ & $0,21 \pm 0,09$ & $0,18 \pm 0,04$ & $0,20 \pm 0,03$ & $0,16 \pm 0,06$ & $0,20 \pm 0,05$ \\
\hline
\end{tabular}

Hati antara lain berfungsi untuk membantu dalam metabolisme karbohidrat, protein, lemak, zat besi, sekresi empedu, detoksifikasi, pembentukan sel darah merah, metabolisme, dan penyimpanan vitamin (Ressang, 1984). Pembesaran hati dapat terjadi bila adazat toksit di dalam ransum ataupun air minum (Ressang, 1984). Rataan persentase hati ayam broiler dari semua perlakuan dalam penelitian ini termasuk normal, dengan kisaran 1,99-2,59\%, sesuai dengan Nickel et al. (1977), yaitu 1,7-2.3\%. Ini berarti bahwa dalam tepung kulit pisang kepok fermentasi tidak mengandung zat-zat toksit atau senyawa-senyawa yang ada dalam bahan tersebut masih dapat ditolerir oleh ayam broiler sampai level penggunaan $10 \%$ dalam ransum selama periode finisher.

Pankreas berfungsi mensekresikan enzim antara lain tripsin yang berperan dalam proses pencernaan protein dan enzim amylase yang berperan dalam proses pencernaan karbohidrat (Anggorodi, 1985). Kandungan serat kasar dalam ransum dapat mempengaruhi bobot pankreas (Natsir, 2008). Rataan bobot pankreas ayam broiler dari semua perlakuan dalam penelitian ini berkisar 3,00-3,75 g tidak jauh berbeda dengan yang dilaporkan oleh Sturkie (1976), yaitu 2,5-4,0 g. Meskipun tepung kulit pisang kepok fermentasi mengandung serat kasar yang tinggi, pemberian selama periode finisher tidak mengakibatkan pemberatan kerja pankreas. Berat dan persentasehati dan pankreasayam broiler dari semua perlakuan diperlihatkan pada Gambar 3. 
g

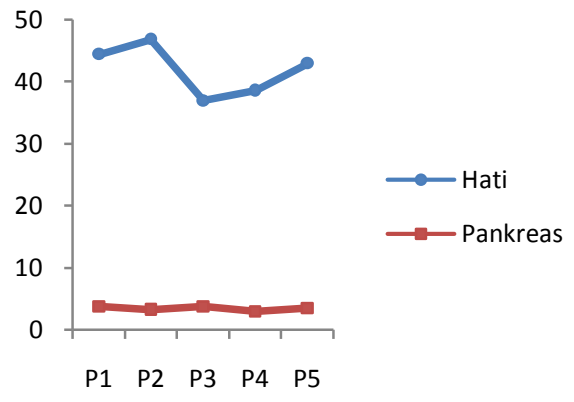

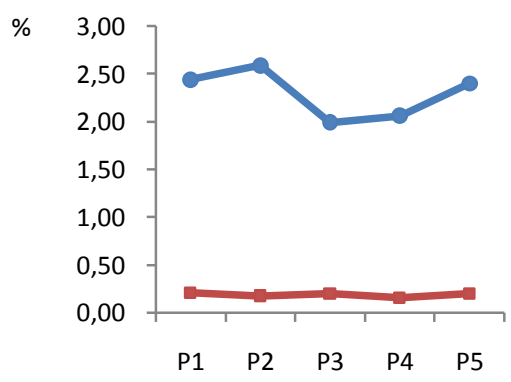

Gambar 3. Berat dan Persentase Hati dan Pankreas Ayam Broiler Penelitian dari Semua Perlakuan

\section{Berat dan Persentase Organ Sirkulasi}

Rataan berat dan persentase beberapa organ sirkulasi ayam broiler yang diberi ransum komersil yang disubstitusi dengan tepung kulit pisang kepok fermentasi + bungkil kelapa + feed supplement selama periode finisher (4-5 minggu) diperlihatkan pada Tabel 4 . Hasil sidik ragam menunjukkan bahwa pemberian tepung kulit pisang kepok fermentasi+bungkil kelapa+feed supplement tidak berpengaruh nyata $(\mathrm{P}>0.05)$ terhadap rataan berat dan persentase jantung, darah, dan limpa ayam broiler. Rataan persentase jantung, darah, dan limpa ayam broiler dalam penelitian ini termasuk dalam batas normal. Hal ini menunjukkan bahwa tepung kulit pisang kepok fermentasitidak memberikan pengaruh negatif terhadap organ sirkulasi ayam broiler.

Tabel 4. Berat dan Persentase Beberapa Organ Sirkulasi Ayam Broiler yang Diberi Ransum Komersil yang Disubstitusi Tepung Kulit Pisang Fermentasi+Bungkil Kelapa+Feed Supplement selama Periode Finisher

\begin{tabular}{|c|c|c|c|c|c|c|}
\hline \multirow[b]{2}{*}{ Parameter } & & \multicolumn{5}{|c|}{ Ransum } \\
\hline & & $\begin{array}{c}0 \% \mathrm{RK}+0 \% \\
\mathrm{TKP}+0 \% \\
\mathrm{BK}+0 \% \mathrm{FS} \\
\left(\mathrm{P}_{1}\right)\end{array}$ & $\begin{array}{c}95 \% \mathrm{RK}+2.5 \% \\
\mathrm{TKP}+1.5 \% \mathrm{BK}+ \\
1 \% \mathrm{FS} \\
\left(\mathrm{P}_{2}\right)\end{array}$ & $\begin{array}{c}91 \% \mathrm{RK}+5 \% \\
\mathrm{TKP}+3 \% \\
\mathrm{BK}+1 \% \mathrm{FS} \\
\left(\mathrm{P}_{3}\right)\end{array}$ & $\begin{array}{c}87 \% \mathrm{RK}+7.5 \% \\
\mathrm{TKP}+4.5 \% \\
\mathrm{BK}+1 \% \mathrm{FS} \\
\left(\mathrm{P}_{4}\right)\end{array}$ & $\begin{array}{c}83 \% \mathrm{RK}+10 \% \\
\mathrm{TKP}+6 \% \mathrm{BK}+ \\
1 \% \mathrm{FS} \\
\left(\mathrm{P}_{5}\right)\end{array}$ \\
\hline Jantung & (g) & $6,50 \pm 1,93$ & $5,50 \pm 1,31$ & $5,63 \pm 1,30$ & $5,00 \pm 0,76$ & $5,25 \pm 0,89$ \\
\hline & $(\%)$ & $0,36 \pm 0,14$ & $0,30 \pm 0,06$ & $0,30 \pm 0,08$ & $0,27 \pm 0,03$ & $0,29 \pm 0,04$ \\
\hline Limpa & $\begin{array}{l}(\mathrm{g}) \\
(\%)\end{array}$ & $\begin{array}{l}2,13 \pm 0,35 \\
0,12 \pm 0,04\end{array}$ & $\begin{array}{l}1,25 \pm 0,73 \\
0,07 \pm 0,04\end{array}$ & $\begin{array}{l}1,25 \pm 0,80 \\
0,07 \pm 0,04\end{array}$ & $\begin{array}{l}1,88 \pm 0,64 \\
0,10 \pm 0,03\end{array}$ & $\begin{array}{l}1,50 \pm 0,71 \\
0,08 \pm 0,04\end{array}$ \\
\hline $\begin{array}{c}\text { Darah } \\
(\%)\end{array}$ & $(\mathrm{g})$ & $\begin{array}{c}37,25 \pm 14,83 \\
2,01 \pm 0,76\end{array}$ & $\begin{array}{c}41,00 \pm 12,69 \\
2,31 \pm 0,83\end{array}$ & $\begin{array}{c}64,50 \pm 26,82 \\
3,47 \pm 1,49\end{array}$ & $\begin{array}{c}49,00 \pm 17,90 \\
2,63 \pm 0,92\end{array}$ & $\begin{array}{c}49,00 \pm 14,00 \\
2,72 \pm 0,67\end{array}$ \\
\hline
\end{tabular}

Peranan jantung adalah sebagai pemompa darah dalam sistem sirkulasi atau transportasi tubuh (Ressang, 1984). Pembesaran jantung dapat terjadi bila ada akumulasi racun pada otot jantung (Frandson, 1992). Rataan persentase bobot jantung ayam broiler dari semua perlakuan dalam penelitian ini termasuk normal, dengan kisaran 0,27-0,36\%, tidak jauh berbeda dengan laporan Ressang (1984), yaitu 0,50-1,42\%. Ini memperkuatbahwa tidak terindikasi adanya zat-zat toksit di dalam tepung kulit pisang kepok fermentasi.

Limpa berfungsi sebagai penyaring darah dan menyimpan zat besi untuk dimanfaatkan kembali dalam sintesis hemoglobin (Dellman dan Brown, 1989). Rataan persentase limpa ayam broiler dari semua perlakuan dalam penelitian ini berkisar $0,07-0,12 \%$ tidak jauh berbeda dengan yang dilaporkan oleh Herawati (1985), yaitu 0,11-0,16\%. Pemberian tepung 
kulit pisang kepok fermentasi sampai $10 \%$ di dalam ransum selama periode finisher tidak mengakibatkan terganggunya kerja limpa.

Peranan darah adalahmembawa zat-zat makanan ke seluruh tubuh. Volume darah akan mempengaruhi distribusi zat nutrisi. Dari tabel terlihat bahwa meskipun secara statistik tidak berbeda nyata, ayam-ayam broiler yang diberikan ransum yang mengandung tepung kulit pisang kepok fermentasi+bungkil kelapa+feed supplement $\left(\mathrm{P}_{2}-\mathrm{P}_{5}\right)$ cenderung memiliki persentase darah lebih tinggi dibandingkan ayam broiler yang diberikan $100 \%$ ransum komersil $\left(\mathrm{P}_{1}\right)$. Hal ini membantu ayam-ayam broiler mendapatkan zat gizi lebih banyak. Meskipun demikian, rataan persentase darah ayam broiler dari semua perlakuan dalam penelitian ini termasuk normal, dengan kisaran 2,01-3,47\%, tidak jauh berbeda dengan yang dilaporkan oleh Ensminger (1989), yaitu 3,5\%. Hal ini menunjukkan bahwa pemberian tepung kulit pisang kepok fermentasi+bungkil kelapa tidak menyebabkan berkurangnya volume darah ayam broiler. Berat dan persentase jantung dan darah ayam broiler dari semua ransum perlakuan diperlihatkan pada Gambar 4.
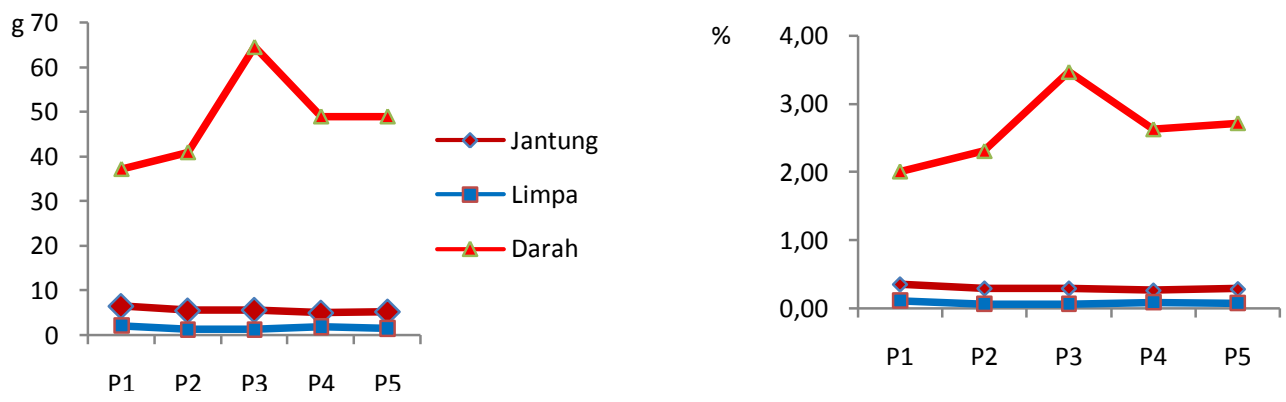

Gambar 4. Berat dan Persentase Jantung, Limpa, dan Darah Ayam Broiler Penelitian dari Semua Perlakuan

Hasil sidik ragam memperlihatkan bahwa kelompok berat badan awal tidak berpengaruh nyata $(\mathrm{P}>0.05)$ terhadap rataan berat dan persentase jantung, limpa, dan darah ayam broiler. Ini berarti bahwa bobot badan tidak begitu mempengaruhi persentase organorgan sirkulasi ayam broiler. Ayam dengan bobot badan rendah maupun tinggi memiliki persentase organ sirkulasi yang relatif sama.

\section{Berat dan Persentase Lemak Abdomen}

Rataan berat dan persentase lemak abdomen ayam broiler yang diberi ransum komersil yang disubstitusi dengan tepung kulit pisang kepok fermentasi + bungkil kelapa + feed supplement selama periode finisher (4-5 minggu) diperlihatkan pada Tabel 5. Hasil sidik ragam memperlihatkan bahwa pemberian tepung kulit pisang kepok fermentasi+bungkil kelapa+feed supplement selama periode finishertidak berpengaruh nyata $(\mathrm{P}>0.05)$ terhadap rataan berat dan persentase lemak abdomen ayam broiler. Hal ini memperlihatkan bahwa ransum-ransum dengan substitusi tepung kulit pisang kepok fermentasi + bungkil kelapa + feed supplement memiliki ratio energi, protein, dan zat-zat gizi lainnya sama baiknya dengan ransum kontrol (100\% ransum komersil). Seperti yang dikatakan oleh Anggorodi (1985), penimbunan lemak tubuh dapat terjadi diakibatkan kelebihan energi di dalam ransum yang dapat dikarenakan ratio energi dan protein terlalu besar.

Hasil analisis kandungan zat gizi ransum penelitian berdasarkan perhitungan (Tabel 1) memperlihatkan kandungan protein dan zat-zat gizi lainnya antar semua perlakuan relatif sama. Meskipun kandungan protein tepung kulit pisang kepok fermentasi lebih rendah, adanya penggunaan bungkil kelapa menaikkan kembali kadar protein ransum, sedangkan zatzat gizi lainnya dilengkapi oleh feed supplement. Akan tetapi, bungkil kelapa memiliki energi 
metabolisme yang rendah, kekurangan energi ini dilengkapi oleh tepung kulit pisang kepok fermentasi. Seperti yang dikatakan oleh Widjastuti dan Hernawan (2012), kulit pisang mengandung karbohidrat sebagai sumber energi. Dengan demikian, sangat kecil kemungkinan terjadinya kelebihan energi di dalam ransum perlakuan yang dapat menyebabkan kenaikan penimbunan lemak tubuh. Kandungan energi metabolisme (EM) di dalam ransum perlakuan tidak dapat dihitung dikarenakan tidak adanya informasi kandungan EM tepung kulit pisang kepok fermentasi.

Tabel 5. Berat dan Persentase Lemak Abdomen Ayam Broiler yang Diberi Ransum Komersil yang Disubstitusi Tepung Kulit Pisang Fermentasi+Bungkil Kelapa+Feed Supplement selama Periode Finisher

\begin{tabular}{|c|c|c|c|c|c|}
\hline \multirow[b]{2}{*}{ Parameter } & \multicolumn{5}{|c|}{ Ransum } \\
\hline & $\begin{array}{c}0 \% \mathrm{RK}+0 \% \\
\mathrm{TKP}+0 \% \\
\mathrm{BK}+0 \% \mathrm{FS} \\
\left(\mathrm{P}_{1}\right)\end{array}$ & $\begin{array}{c}95 \% \mathrm{RK}+2.5 \% \\
\mathrm{TKP}+1.5 \% \mathrm{BK} \\
+1 \% \mathrm{FS} \\
\left(\mathrm{P}_{2}\right)\end{array}$ & $\begin{array}{c}91 \% \mathrm{RK}+5 \% \\
\mathrm{TKP}+3 \% \\
\mathrm{BK}+1 \% \mathrm{FS} \\
\left(\mathrm{P}_{3}\right)\end{array}$ & $\begin{array}{c}87 \% \mathrm{RK}+7.5 \% \\
\mathrm{TKP}+4.5 \% \\
\mathrm{BK}+1 \% \mathrm{FS} \\
\left(\mathrm{P}_{4}\right)\end{array}$ & $\begin{array}{c}83 \% \mathrm{RK}+10 \% \\
\mathrm{TKP}+6 \% \mathrm{BK}+1 \\
\% \mathrm{FS} \\
\left(\mathrm{P}_{5}\right)\end{array}$ \\
\hline $\begin{array}{r}\text { Lemak Abdomen }(\mathrm{g}) \\
(\%)\end{array}$ & $\begin{array}{c}36,25 \pm 7,15 \\
1,97 \pm 0,46 \\
\end{array}$ & $\begin{array}{l}37,63 \pm 8,00 \\
2,10 \pm 0,50\end{array}$ & $\begin{array}{c}31,63 \pm 9,13 \\
1,69 \pm 0,44 \\
\end{array}$ & $\begin{array}{c}32,13 \pm 8,49 \\
1,73 \pm 0,54\end{array}$ & $\begin{array}{c}35,88 \pm 7,88 \\
1,98 \pm 0,31 \\
\end{array}$ \\
\hline
\end{tabular}

Hasil sidik ragam memperlihatkan bahwa kelompok berat badan awal tidak berpengaruh nyata $(\mathrm{P}>0.05)$ terhadap rataan berat dan persentase lemak abdomen ayam broiler. Akan tetapi, ayam-ayam dari kelompok berat badan yang lebih besar cenderung memiliki rataan berat lemak abdomen yang lebih tinggi pula. Namun, secara persentase, ayam-ayam dari kelompok berat badan yang lebih besar cenderung memiliki rataan persentase lemak abdomen yang lebih rendah. Hal ini menunjukkan bahwa ayam-ayam yang berbobot badan lebih besar lebih efisien memanfaatkan zat gizi ransum dibandingkan dengan ayam-ayam yang berbobot badan lebih rendah.
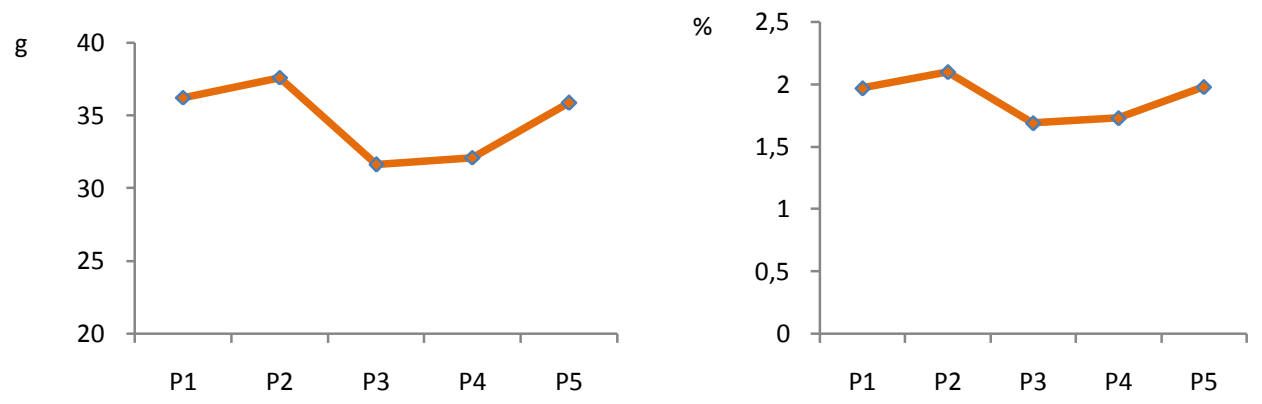

Gambar 5. Berat dan Persentase Lemak Abdomen Ayam Broiler Penelitian dari Semua Perlakuan

\section{Berat dan Persentase Organ Luar}

Rataan berat dan persentase beberapa organ luar ayam broiler yang diberi ransum komersil yang disubstitusi dengan tepung kulit pisang kepok fermentasi + bungkil kelapa + feed supplement selama periode finisher (4-5 minggu) diperlihatkan pada Tabel 6. Hasil sidik ragam menunjukkan bahwa pemberian tepung kulit pisang kepok fermentasi+bungkil kelapa+feed supplementselama periode finishertidak berpengaruh nyata $(\mathrm{P}>0.05)$ terhadap rataan berat dan persentase bulu dan shank ayam broiler, namun nyata $(\mathrm{P}<0.05)$ menurunkanrataan berat kepala+leher dan sangat nyata $(\mathrm{P}<0.01)$ menurunkan rataan persentase kepala+leher ayam broiler. Hal ini menunjukkan bahwa tepung kulit pisang kepok fermentasi memberikan pengaruh positif terhadap organ luar ayam broiler. 
Dari tabel dapat dilihat bahwa penggunaan tepung kulit pisang kepok fermentasi+bungkil kelapa+feed supplement sebagai substitusi sebagian ransum komersil selama periode finisher menurunkan rataan berat dan persentase kepala+kaki ayam broiler. Ayam broiler yang diberi substitusi ransum komersil dengan $10 \%$ tepung kulit pisang kepok fermentasi $+6 \%$ bungkil kelapa $+1 \%$ feed supplement $\left(\mathrm{P}_{5}\right)$ nyata memiliki rataan berat kepala+leher lebih rendah dan sangat nyata memiliki rataan persentase karkas kepala+leher lebih rendah dibandingkan dengan ayam broiler yang diberi $100 \%$ ransum komersil. Hal ini diduga adanya peranan feed supplement yang digunakan di dalam ransum substitusi yang mengandung mineral (Mn, Fe, Zn, Co, I), vitamin (A, D, E, K, C, B1, B2, B12, niacin, panthothenat), dan asam amino (methionine dan lysine). Zat-zat nutrisi ini kemungkinan terdistribusi ke pembentukan jaringan daging. Berdasarkan Murtidjo (1992), feed supplement yang banyak dipergunakan dalam ransum unggas biasanya bertujuan untuk melengkapi kekurangan asam amino, vitamin, dan mineral. Senyawa-senyawa ini sangat berperan dalam metabolisme tubuh.

Kepala+leher merupakan organ non-karkas yang memiliki nilai ekonomis yang rendah karena banyak tersusun dari tulang dan sedikit daging. Pengamatan rekan se-tim penelitian memperlihatkan, ayam broiler yang mendapatkan ransum komersil dengan substitusi tepung kulit pisang kepok fermentasi + bungkil kelapa + feed supplementmemiliki persentase dada lebih tinggi dan persentase punggung dan sayap lebih rendah, sedangkan persentase paha relatif sama. Komponen daging karkas paling banyak terdapat pada bagian dada, sedangkan paling sedikit terdapat pada punggung dan sayap.

Tabel 6. Berat dan Persentase Beberapa Organ Luar Ayam Broiler yang Diberi Ransum Komersil yang Disubstitusi Tepung Kulit Pisang Fermentasi+Bungkil Kelapa+Feed Supplement selama Periode Finisher

\begin{tabular}{lcccccc}
\hline & & \multicolumn{5}{c}{ Ransum } \\
& & \multicolumn{5}{c}{ Komersil+Tepung Kulit Pisang Fermentasi+ } \\
Bungkil Kelapa+Feed Supplement
\end{tabular}

Ayam-ayam penelitian ini memiliki persentase organ non karkas bagian luar luar, yang terdiri dari bulu, kepala+leher, dan shank berturut-turut 4,13-4,95\%, 2,99-3,41\%, dan 3,21-3,42\% lebih rendah dari yang dilaporkan oleh Ensminger (1989), yaitu bulu 6\%, kaki $3,90 \%$, dan kepala+leher $5,60 \%$. Ini bisa dikarenakan perbedaan bobot badan ayam. Bobot badan yang tinggi umumnya akan menghasilkan persentase karkas yang tinggi dan persentase non karkas yang lebih rendah. Ayam penelitian ini berarti lebih baik karena bagian luar non karkas kurang memiliki nilai ekonomis.

Hasil sidik ragam memperlihatkan bahwa kelompok berat badan berpengaruh sangat nyata $(\mathrm{P}<0.01)$ terhadap rataan berat bulu dan nyata $(\mathrm{P}<0.05)$ terhadap berat kepala+leher. Shank, meskipun secara statistik tidak nyata $(\mathrm{P}>0,05)$, ayam broiler dari kelompok berat 
badan lebih tinggi memiliki rataan berat shank, bulu dan kepala+leher relatif lebih tinggi pula. Hal ini dikarenakan bagian-bagian tubuh luar, seperti kepala, leher, bulu, dan shank berkaitan dengan bobot badan. Akan tetapi, secara persentase, meskipun tidak ada perbedaan nyata, berat bulu dan shank antara ayam dari kelompok berat badan lebih rendah dengan ayam dari kelompok berat badan yang lebih tinggi, ayam broiler dari kelompok berat badan lebih tinggi relatif memiliki rataan persentase bulu dan shank lebih rendah. Ini berarti bahwa ayam broiler dengan berat badan lebih tinggi lebih efisien memanfaatkan protein untuk pembentukan jaringan karkas daripada jaringan non-karkas (bulu, kepala+leher, dan shank).
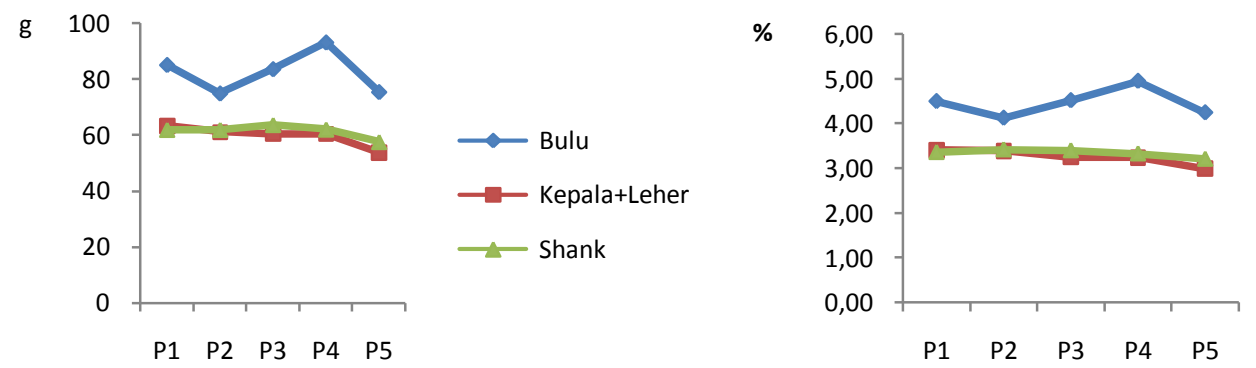

Gambar 6. Berat dan Persentase Bulu, Kepala+Leher, dan Shank Ayam Broiler Penelitian dari Semua Perlakuan

\section{Mortalitas}

Jumlah ayam yang mati selama penelitian dari semua perlakuan adalah 8 ekor (8\%). Kematian ayam ini bukan disebabkan pengaruh perlakuan penggunaan tepung kulit pisang fermentasi+bungkil kelapa+feed supplement, karena kematian juga ditemui pada perlakuan kontrol $\left(\mathrm{P}_{1}\right)$. Mortalitas ayam broilerayam broiler dari setiap perlakuan diperlihatkan pada Tabel 7.

Tabel 7. Mortalitas Ayam Broiler Penelitian dari Setiap Perlakuan

\begin{tabular}{|c|c|c|c|c|c|}
\hline \multirow[b]{2}{*}{ Parameter } & \multicolumn{5}{|c|}{ Ransum Kon } \\
\hline & $\begin{array}{c}0 \% \mathrm{RK}+0 \% \\
\mathrm{TKP}+0 \% \\
\mathrm{BK}+0 \% \mathrm{FS} \\
\left(\mathrm{P}_{1}\right)\end{array}$ & $\begin{array}{c}95 \% \mathrm{RK}+2.5 \% \\
\mathrm{TKP}+1.5 \% \mathrm{BK}+ \\
1 \% \mathrm{FS} \\
\left(\mathrm{P}_{2}\right)\end{array}$ & $\begin{array}{c}91 \% \mathrm{RK}+5 \% \\
\mathrm{TKP}+3 \% \\
\mathrm{BK}+1 \% \mathrm{FS} \\
\left(\mathrm{P}_{3}\right)\end{array}$ & $\begin{array}{c}87 \% \mathrm{RK}+7.5 \% \\
\mathrm{TKP}+4.5 \% \\
\mathrm{BK}+1 \% \mathrm{FS} \\
\left(\mathrm{P}_{4}\right)\end{array}$ & $\begin{array}{c}83 \% \mathrm{RK}+10 \% \\
\mathrm{TKP}+6 \% \mathrm{BK}+ \\
1 \% \mathrm{FS} \\
\left(\mathrm{P}_{5}\right)\end{array}$ \\
\hline Mortalitas (ekor) & 2 & 2 & 1 & 2 & 1 \\
\hline Mortalitas (\%) & 10 & 10 & 5 & 10 & 5 \\
\hline
\end{tabular}

$\mathrm{RK}=$ Ransum komersil broiler, $\mathrm{TKP}=$ Tepung kulit pisang fermentasi, $\mathrm{BK}=$ Bungkil kelapa, $\mathrm{FS}=$ Feed supplement

Berdasarkan pengamatan, kematian ayam disebabkan stress cuaca panas.Pada saat dilakukan penelitian, suhu mencapai $37{ }^{\circ} \mathrm{C}$ mengakibatkan beberapa ekor ayam kesulitan mengeluarkan panas dari tubuhnya sehingga badan menjadi lemah dan akhirnya mati. Sesuai Griffin et al. (2005), suhu merupakan faktor lingkungan yang sangat berpengaruh pada pemeliharaan ayam broiler, pada suhu tinggi broiler mudah mengalami stress.

\section{KESIMPULAN DAN SARAN}

\section{Kesimpulan}

Berdasarkan hasil penelitian yang telah dilakukan dapat disimpulkan bahwa tepung kulit pisang fermentasi kepok fermentasi dapat digunakan hingga $10 \%$ untuk mensubstitusi ransum komersil dengan penambahan bungkil kelapa sebanyak-banyaknya $6 \%$ dan feed supplement $1 \%$ selama periode finisher tanpa berpengaruh negatif terhadap berat dan persentase organorgan dalam ayam broiler. Penggunaan tepung kulit pisang fermentasi kepok fermentasi 
cenderung menurunkan persentase organ-organ nonkarkas bagian luar (bulu, kepala+leher, dan shank) ayam broiler.

\section{Saran}

Berdasarkan hasil penelitian yang telah dilakukan disarankan bahwa penggunaan tepung kulit pisang kepok fermentasi dilakukan selama periode finisher (4-5 minggu) dan sebaiknya digunakan tidak melebihi $10 \%$ sebagai substitusi ransum komersil ayam broiler. Perlu dilakukan penelitian lanjut tentang penggunaan kulit pisang fermentasi pada jenis unggas lainnya, terutama itik, ayam kalasan, dan ayam buras.

\section{DAFTAR PUSTAKA}

Anggorodi, R. 1985. Kemajuan Mutakhir dalam Ilmu Makanan Ternak Unggas. UI Press, Jakarta.

Dellman, H. D. dan E. M. Brown. 1989. Buku Teks Histologi Veteriner I. Ed. ke-3. Penerbit Universitas Indonesia, Jakarta.

Ensminger, M. O. 1989. Poultry Science. The Interstate Printer and Publiser, Denvile.

Frandson, R. D. 1992. Anatomi dan Fisiologi Ternak. Alih Bahasa oleh B. Srigandono dan Koen Praseno. Gadjah Mada University Press, Yogyakarta.

Griffin, A.M., R.A. Renemar, F. E. Robinson, and M. J. Zuidhof. 2005. The influence of rearing light period and the use of broiler or broiler breeder diets on forty-two-day body weight, fleshing, and flock uniformity in broiler stocks. Journal of Apllied Poultry Research 14 (2): 204-216.

Hartadi, H., S. Reksohadiprodjo, S.Lebdosukojo, dan A.D. Tillman. 1980. Tabel-tabel dari Komposisi Bahan Makanan Ternak untuk Indonesia (Tables of Feed Composition for Indonesia). The International Feedstuff Institute.Utah Agricultural Experiment Station.Utah State University, Logan, Utah.

Herawati, L. 1985. Pengaruh Pemberian Probiotikum dalam Ransum Ayam Pedaging Terhadap Beberapa Organ Tubuh. Karya Ilmiah. Fakultas Peternakan Institut Pertanian Bogor, Bogor.

Hernawati dan A. Aryani. 2007. Kajian Sifat Fisik dan Kimia Tepung Kulit Pisang Hasil Pengeringan Oven dan Jemur. FPMIPA Universitas Pendidikan Indonesia, Bandung.

Kismono, S. S. 1986. Toleransi Ayam Broiler terhadap Kandungan Serat Kasar, Serat Detergent Asam, Lignin dan Silika dalam Ransum yang Mengandung Tepung Daun Alang-Alang. Disertasi. Fakultas Pascasarjana Institut Pertanian Bogor, Bogor.

Koni, T. N. I. 2009. Pemanfaatan tepung kulit pisang hasil fermentasi dengan jamur tempe (Rhyzopus oligosporus) dalam ransum terhadap pertumbuhan broiler (tesis S2). Universitas Nusa Cendana, Kupang.

Koni, T. N. I., A. Paga, dan T.A. Foenay. 2006. Substitusi Jagung dengan Campuran Kulit Pisang dan Ampas Kelapa Dalam Ransum Ayam pedaging. Kupang. Laporan Hasil Penelitian Politani.

Natsir, M. H. 2008. Pengaruh penggunaan kombinasi asam sitrat dan asam laktat cair dan ternak apsulasi sebagai asitf pakan terhadap persentase karkas dan berat organ dalam ayam pedaging.Jurnal Nutrisi dan Makanan Ternak. Fakultas Peternakan, Universitas Brawijaya, Malang.

Nickel, R. A., A. Schummer, E. Seiferie, W. G. Siller, and R.A.L. Wight. 1977. Anatomy of The Domestic Birds. Verlag Paul Parey, Berlin.

Pond, W.G., D. C. Church, and K. R. Pond. 1995. Basic Animal Nutrition and Feeding. $4^{\text {th }}$ Ed. John Willey and Sons, Canada. 
Ramli, N., D. M. Suci, S. Sunanto, C. Nugraheni, A. Yulifah, dan A. Sofyan. 2008. Performan ayam broiler yang diberi ransum mengandung potassium diformate sebagai pengganti flavomycin. Agripet. Vol. 8. No. 1: 1-8.

Ressang, A. A. 1984. Patologi Khusus Veteriner. Gadjah Mada University Press, Yogyakarta.

Steel, R. G. D. dan J. H. Torrie., 1993.Prinsip dan Prosedur Statistika (Pendekatan Biometrik) Penerjemah B. Sumantri. Gramedia Pustaka Utama, Jakarta.

Sturkie, P. D. 1976. Avian Digestion in Duck Physiology of Domestic Animal. $8^{\text {th }}$ Ed. Comstock Publishing Association, Itacha, London.

Sudaryani, T. dan H. Santosa, 2003. Pembibitan Ayam Ras. Cet. ke-7. Penebar Swadaya, Jakarta.

Udjianto, A., E. Rostianti, dan D.R. Purnama. 2005. Pengaruh pemberian limbah kulit pisang fermentasi terhadap pertumbuhan ayam pedaging dan analisa usaha. Prosiding Temu Teknis Nasional Tenaga Fungsional Pertanian, Bogor 2005: 76-81.

Widjastuti, T. dan E. Hernawan. 2012. Utilizing of banana peel (Musa Sapientum) in the ration and its influence on final body weight, percentage of carcass and abdominal fat on broilers under heat stress condition. Journal of Animal Physiologi and Animal Nutrition 83: $57-64$.

Zamora, A.F., M. R. Calapardo, K.P. Rosano, E.S. Luis, dan F. Dalmacio. 1989. Improvement of copra meal quality for use in animal feeds. Proc. FAP/UNDP Workshop on Biotechnology in Animal Production and Health in Asia and Latin America: 312-320.

\section{UCAPAN TERIMAKASIH}

Penulis menyampaikan terima kasih yang sebesar-besarnya kepada Syairazi, Rismanda Sari, dan Yeyen Safitri atas kerjasamanya yang baik selama penelitian serta semua pihak yang turut membantu dalam penelitian ini. 